Article type: Review

\title{
Targeted cancer therapy: interactions with other medicines
}

David Conde-Estévez ${ }^{1,2}$ PharmD, Ph.D. BCOP MSc.,

${ }^{1}$ Department of Pharmacy. Hospital Universitari del Mar, Barcelona, Spain

${ }^{2}$ Hospital del Mar Medical Research Institute (IMIM), Barcelona, Spain

-Corresponding author. Mailing address: Dr. David Conde-Estévez, Department of Pharmacy, Hospital Universitari del Mar, Parc de Salut Mar. Passeig Marítim 25-29, E-08003 Barcelona, Spain. Phone: +34-93-2483851. Fax: +34-93-2483256. E-mail: dconde@ hospitaldelmar.cat 


\section{Abstract}

Targeted therapy drugs, mainly those within the signal transduction inhibitors, are used more chronically than cytotoxic drugs and are metabolised by cytochrome P450 isozymes so patients are at high risk of having drug-drug interactions (DDI). Not only this, as the majority of them are given orally, new drug-drug interactions concerning gastrointestinal absorption can occur (e.g., with proton pump inhibitors). DDI can lead to changed systemic exposure, resulting in variations in drug response of the co-administered. In addition, concomitant ingestion of dietary supplements could also alter systemic exposure of drugs, thus leading to adverse drug reactions or loss of efficacy. In this review, we give and overview of the current existing data of known or suspected DDI between targeted therapy and other medicines.

A review of package inserts was performed to identify drug-drug interactions for all targeted antineoplastic agents. Tertiary databases such as Lexicomp®, Drugs, Martindale, Facts and Comparisons ${ }^{\circledR}$, and AHFS Drug Information were also referenced.

Our study covered 40 targeted antineoplastic agents (28 signal transduction inhibitors, 9 monoclonal antibodies and 3 other drugs, two monoclonal antibody conjugates and one fusion protein). Most of targeted therapy drugs are major CYP3A4 substrates with P-gp playing an important role in disposition too. Thus, there is a very common thread here that these agents will likely be sensitive victims to strong CYP3A4/P-gp inhibitors and inducers.

It is essential that health care providers monitor patients for potential DDI to avoid a loss in efficacy or risk of greater toxicity from targeted therapy.

Key words: drug-drug interactions, pharmacology, medication review, molecular targeted therapy 


\section{Introduction}

Over the past few years, there has been a paradigm shift in cancer treatment from more unspecific agents (cytotoxic drugs) to target based therapies with many of the newly approved anticancer agents against specific molecular targets. Targeted cancer therapies are drugs that block the growth and spread of cancer by interfering with specific molecules ("molecular targets") that are involved in the growth, progression, and spread of cancer. Targeted cancer therapies are sometimes called "molecularly targeted drugs," "molecularly targeted therapies," "precision medicines," or similar names [1]. The two main groups of targeted therapy are monoclonal antibodies and the signal transduction inhibitors, being the tyrosine kinase inhibitors the most promising drugs nowadays [2].

Among these drugs, signal transduction inhibitors, are used more chronically and are mainly metabolised by cytochrome P450 (CYP) isozymes so patients are at high risk of having drug-drug interactions (DDI). Not only this, as the majority of targeted therapy drugs are given orally, new drugdrug interactions concerning gastrointestinal absorption can occur (e.g., with proton pump inhibitors). DDI can lead to changed systemic exposure, resulting in variations in drug response of the coadministered drugs [3]. In addition to co-administration of other drugs, concomitant ingestion of dietary supplements could also alter systemic exposure of drugs, thus leading to adverse drug reactions or loss of efficacy. Furthermore, DDI may be associated with serious or even fatal events. In fact, DDI are estimated to account for approximately $4 \%$ of deaths among patients with cancer [4].

In addition, DDI is an important issue among cancer population. It is commonly observed in these patients, as they often receive multiple medications concurrently. It was shown previously that patients who are taking multiple medications for the treatment of comorbid illnesses experience an increased incidence of drugs interactions [5, 6]. However, the real incidence of DDI in cancer patients is unknown because the studies have evaluated it among patients with various medical conditions and different kind of anticancer drugs.

DDI can be classified into those that are pharmacokinetic and those that are pharmacodynamic [7]. Pharmacokinetic interactions arise when absorption, distribution, metabolism, or elimination of the involved drugs are altered, leading to changes in the amount and duration of drug availability at receptor sites. The most common pharmacokinetic DDI concern is absorption (incomplete drug absorption is a risk of drug interaction) and metabolism by the cytochrome P450 isozymes. 
Pharmacodynamic interactions usually refer to alterations of pharmacological effects. The effect can be synergistic, additive, or antagonist.

Transporter-based interactions have been increasingly documented. Various reported interactions attributed earlier to other mechanisms of interaction, such as protein-displacement or enzyme inhibition/induction, may be due in part to the inhibition or induction of transport proteins, such as $\mathrm{P}$ glycoprotein (P-gp), organic anion transporter (OAT), organic anion transporting polypeptide (OATP), organic cation transporter (OCT), multidrug resistance-associated proteins (MRP) and breast cancer resistant protein (BCRP).

One common misconception is that targeted therapy is safer and less toxic than intravenous chemotherapy. In fact, targeted therapy have specific toxicity profiles (some toxic effects are severe and even cause secondary tumours) that differ from those of cytotoxic drugs [8]. Furthermore, DDI are ubiquitous among the broad class of targeted therapies, which can contribute to enhanced treatmentrelated toxicities.

The biggest challenge today is to find out which DDI is a relevant one [9]. This question is still unanswered and great debate is growing in the literature $[9,10]$.

In this review, we give and overview of the current existing data of known or suspected DDI between targeted therapy and other medicines.

\section{Methods}

A review of package inserts was performed to identify drug-drug interactions for all targeted antineoplastic agents approved by the EMA. Additionally, tertiary databases such as Lexicomp® (www.lexi.com), Drugs (www.drugs.com), Martindale, Facts and Comparisons $®$ (http://www.wolterskluwercdi.com/), and AHFS Drug Information were also referenced. Each medication was individually evaluated.

The definitions used by the FDA Drug Development and Drug Interactions department for regulatory procedures were assumed for purposes of this review. A drug was defined as an inducer or inhibitor (perpetrator) if the medication raised or lowered the plasma concentration of another medication (victim) that was metabolized by that enzyme. A drug was considered to be a strong inhibitor or inducer if its interactions caused change in the area under the plasma concentration-time profile (AUC) 
of a substrate by at least five-fold or changed the clearance of a medication higher than $80 \%$. A drug was classified as a moderate inhibitor or inducer if its interactions changed the AUC of a substrate by at least two- to five-fold or changed the clearance of a medication by $50 \%$ to $80 \%$. A drug was deemed to be a weak inhibitor or inducer if its interaction changed the AUC by 1.25- to two-fold or changed the clearance of a medication by $20 \%$ to $50 \%$ [11]. This categorization was applied in the table 2 using the following symbols: as the victim drug “*” indicating major substrate (as a victim drug) and “.” referring to minor substrate; and as the perpetrator drug, "+" representing weak inducer/inhibitor; "++" for moderate inducer/inhibitor; and “+++" designating strong inducer/inhibitor.

In addition, targeted therapy drugs were also analysed for interactions with acid suppressor medications such as proton-pump inhibitors, histamine 2-receptor antagonists and antiacids. Each agent was also evaluated for its effects on coumarin-containing products and for QTc-interactions, defined as drug combinations with potential QTc-interval prolongation and/or torsades de pointes inducing properties. These interactions were categorized as yes, no or not studied.

All this research was summarized in a table and several recommendations were also included.

\section{Results}

Our review covered 40 targeted antineoplastic agents (28 signal transduction inhibitors, 9 monoclonal antibodies and 3 other drugs, two monoclonal antibody conjugates and one fusion protein- see table 1 for more detailed information).

1. Signal transduction inhibitors $(n=28)$ [Table 2]

The CYP enzyme class was predominant for metabolisation of these drugs. The P-gp were also involved for $15(53.6 \%)$ medications. The majority of the medications analysed were substrates for multiple enzymes and/or transporters in their metabolism, the most prevalent combination of which was CYP enzymes plus P-gp.

Moreover, the addition of a targeted therapy agent to an anticoagulant may have variable effects on the international normalization ratio (INR). Approximately half of the signal transduction inhibitors $(\mathrm{n}=13)$ affected the absorption of coumarin-derived anticoagulants, and prolongation of the QTc interval was significant in 12 agents. Additionally, any other DDI that had specific dose-modification recommendations available in the package insert or through tertiary databases were listed for 13 drugs. Finally, we also noted that acid suppression affected absorption rates for nine targeted therapy drugs. 
2. Monoclonal antibodies and others $(n=12)$ [Table 2]

In general, several pathways have been described that may contribute to the metabolism of antibodies. All of these pathways involve the biodegradation of the antibody to smaller molecules, i.e. small peptides or aminoacids. Normally, no formal interaction studies with MoAb have been performed. As they are usually combined with other cytotoxic drugs, studies can be found regarding possible pharmacodynamic interactions between each agent. For example, cetuximab in combination with capecitabine and oxaliplatin (XELOX) the frequency of sever diarrhoea may be increased.

Two important exceptions (see table 2) were found among antibody-drug conjugates brentuximab and trastuzumab emtasine. Both drugs are composed by a MoAb and covalently linked to another agent (antimicrotubule agent monomethyl aurastin E [MMAE] in case of brentuximab and a maytansine derivated called DM1 in case of trastuzumab emtasine). These agents are released in vivo and are metabolized by CYP as described in table 2.

\section{Discussion}

The major finding of our review is that most of targeted therapy drugs are major CYP3A4 substrates with P-gp playing an important role in disposition too. Thus, there is a very common thread here that these agents will likely be sensitive victims to strong CYP3A4/P-gp inhibitors and inducers. As a result, augmented or reduced exposure by variation of CYP activity might origin clinically significant toxic effects or ineffectiveness of treatment with targeted therapy drug. Specific recommendations concerning dose modifications of each drug or avoidance of concomitancy for such situations are described in table 2. Physicians must be aware of the potential interactions of targeted therapy. In general, MoAb are not implicated in DDI except antibody drug conjugates such as brentuximab or trastuzumab emtasine. Brentuximab is an antibody drug conjugate (ADC) in which approximately 4 molecules of MMAE are linked to a CD30-directed antibody molecule. In vivo data indicate a small amount of MMAE released from the ADC is metabolized. In vitro data indicate that CYP3A4/5 is the primary metabolic pathway for MMAE. In an undefined study, rifampin, a strong CYP3A4 inducer, decreased the exposure to MMAE by approximately 46\%; ketoconazole, a strong CYP3A4 inhibitor, increased the exposure to MMAE by approximately 34\% (information from package insert). 
However, the other group of targeted therapy, the signal transduction inhibitors, have a rather potential DDI with concomitant medication. There is a wide spectrum of recommendations on ways to manage DDI across this broad class of drugs. Although some DDI can be easily managed by an increase in monitoring using laboratory tests and patient tolerance, greater monitoring cannot mitigate the impact of others.

Remarkably, DDI with acid suppression therapy are still not fully understood neither clinical signification nor management. Manufacturers of several other oral chemotherapeutics recommend that avoidance of PPIs be considered. A good example can be erlotinib, while is generally recommended to avoid the concomitant administration with proton pump inhibitors, some recent studies find no relevant interaction between erlotinib and PPI $[12,13]$. In a retrospective review of data from a randomized, placebo-controlled trial conducted in 485 patients with advanced or metastatic non-small cell lung cancer, the average erlotinib Cmin was not significantly different between users and non-users of acid suppression medications (including proton pump inhibitors (PPIs) or H-2 blockers) [13]. Progressionfree and overall survival did not appear to be significantly altered by the use of acid suppressants. The retrospective nature of the study, uncontrolled use of acid suppressants throughout the study period, and lack of monitoring of adherence should also be considered. However, these results do raise questions about the clinical significance of this interaction. In a pharmacokinetic/pharmacodynamic/pharmacogenomic study involving Japanese patients with nonsmall cell lung cancer, erlotinib exposure was similar in patients receiving concurrent gastric acid suppressing medication $(\mathrm{n}=18)$ compared to patients not receiving gastric acid suppressing therapy $(n=38)$ [14]. However, a recent pharmacokinetic study of 24 healthy volunteers, omeprazole decreased the erlotinib AUC and Cmax by $45 \%$ and 54\%, respectively. The AUC and Cmax of the active metabolite of erlotinib (OSI-420) also decreased by $55 \%$ and $60 \%$, respectively [15]. Interestently, the same study found that coadministration of erlotinib 2 hours after ranitidine $(300 \mathrm{mg})$ decreased the AUC and Cmax of erlotinib by $33 \%$ and 54\%, respectively. The effect of ranitidine on erlotinib exposure was lessened using staggered administration times. Administration of erlotinib with ranitidine (150 mg twice daily) with the erlotinib dose given 10 hours after the evening ranitidine dose and 2 hours before the morning ranitidine dose, resulted in a decrease in the AUC and Cmax of erlotinib by $15 \%$ and $17 \%$, respectively [15]. 
The DDI between coumarin-derived anticoagulants and targeted therapy can potentially elevate INR, so, generally, they can be managed with increased monitoring of INR. Dabrafenib appears to be the only targeted therapy agent that may decrease bioavailability of warfarin.

Another important source of DDI are the complementary and alternative medicine.

In a systematic review of 890 pairs of herb-drug interactions, St. Johns wort was found to cause the majority of herb-drug interactions (147), followed by ginkgo (51) and kava kava (41). Warfarin (105) was identified as the drug most frequently involved, followed by insulin (41) and aspirin (36). Among drugs used in oncology, cases involving cyclosporine (16), heparin (14), and tamoxifen (11) have been reported [16].

Most targeted therapy drugs are eliminated by hepatic metabolism and excreted in faeces as metabolites or unchanged, with no significant contribution of renal clearance. Despite part of drug are eliminated by kidneys, this renal clearance is generally undertaken as inactive metabolites (see table 2). There are no guidelines or standards for determining clinical relevance of interactions via consistent systematic evaluation or classification [17]. One possible approach is to check medication for DDI by using DDI compendia. Nowadays, several commercial DDI compendia are available. It is advisable to consult more than just one DDI information reference source to ensure that is safe to use certain drugs concomitantly [17]. For example, two different compendia (Micromedex and www.drugs.com) were employed by van Leeuwen et al to "maximize accuracy" of the medication review [18]. However, a recent systematic review on interactions between oral antineoplastic agents and concomitant medication was performed by using Micromedex and LexiComp handbook [19]. Moreover, studies have shown that major conflicts exist among drug compendia on DDI information such as severity and evidence ratings.[20] So, which compendia are more advisable? Currently there are no evidence supporting any of them respect the others. Several discrepancies were observed between the different compendia, some of them remarkable. Compendia use differing approaches to identify and evaluate evidence on DDI. It has been reported that the main factors that contributed to the observed discrepancies could be related to different sources of information and the different assumptions to extrapolated DDI of one drug to other drugs within the same class [20].

There are some limitations to the methodology followed in this article. The latest package inserts versions were analysed to identify DDI. Unfortunately, some of the drugs commercially available for a substantial time do not have current studies for specific DDI. Second, certain DDI were not included in 
our analysis because of a pharmacodynamic interaction rather than a pharmacokinetic interaction.

Therefore, it is important for health care professionals to evaluate pharmacodynamic interactions when prescribing oral chemotherapy. Lastly, the literature for anticancer drugs changes rapidly; the information in the tables provided in this article reflects the most current recommendations at the time data were collected. Therefore, it is crucial that health care providers actively review the most current data for DDI before any formal recommendations.

In conclusion, the patient population receiving targeted therapy is increasing rapidly, causing stark changes in the management and treatment of malignancies. It is essential that health care providers monitor patients for potential DDI to avoid a loss in efficacy or risk of greater toxicity from targeted therapy. Oncology pharmacists play an essential role in maintaining patient safety. To do this, a profound assessment not only of co-prescribed drugs, but also herbal supplements, lifestyle food and drinks (eg. Grapefruit juice), cardiac risk factors (QTc interval), and physical examination is needed. Moreover, it is highly recommendable a real collaboration between pharmacist, oncologists and haematologists, as well as other medical specialists to undertake a proper care of these patients.

\section{Informed consent}

Not applicable (not research involving human participants and/or animals).

\section{Conflict of interest}

The authors declare that they have no conflict of interest. 


\section{References}

1. NCI. Targeted Cancer Therapies. In: About Cancer. National Cancer Institute. 2015.

http://www.cancer.gov/about-cancer/treatment/types/targeted-therapies/targeted-therapies-fact-sheet Acessed 30 November 2015

2. Krause DS, Van Etten RA. Tyrosine kinases as targets for cancer therapy. N Engl J Med. 2005;353:172-87.

3. Mathijssen RH, Sparreboom A, Verweij J. Determining the optimal dose in the development of anticancer agents. Nat Rev Clin Oncol. 2014;11:272-81.

4. van Leeuwen RW, Brundel DH, Neef C, van Gelder T, Mathijssen RH, Burger DM et al. Prevalence of potential drug-drug interactions in cancer patients treated with oral anticancer drugs. Br J Cancer. 2013;108:1071-8.

5. Riechelmann RP, Tannock IF, Wang L, Saad ED, Taback NA, Krzyzanowska MK. Potential drug interactions and duplicate prescriptions among cancer patients. J Natl Cancer Inst. 2007;99:592600.

6. Karas S. The potential for drug interactions. Ann Emerg Med. 1981;10:627-30.

7. Scripture CD, Figg WD. Drug interactions in cancer therapy. Nat Rev Cancer. 2006;6:546-58.

8. Stadler WM. New targets, therapies, and toxicities: lessons to be learned. J Clin Oncol. $2006 ; 24: 4-5$.

9. Conde-Estévez D, Echeverría-Esnal D, Tusquets I, Albanell J. Potential clinical relevant drugdrug interactions: comparison between different compendia, do we have a validated method? Ann Oncol. 2015;26:1272.

10. van Leeuwen RW, Mathijssen RH, Jansman FG, van Gelder T. Reply to the letter to the editor 'potential clinical relevant drug-drug interactions: comparison between different compendia, do we have a validated method?' by Conde-Estévez et al. Ann Oncol. 2015;26:1272-3.

11. Huang SM, Strong JM, Zhang L, Reynolds KS, Nallani S, Temple R et al. New era in drug interaction evaluation: US Food and Drug Administration update on CYP enzymes, transporters, and the guidance process. J Clin Pharmacol. 2008;48:662-70.

12. Ter Heine R, Fanggiday JC, Lankheet NA, Beijnen JH, Van Der Westerlaken MM, Staaks GH et al. Erlotinib and pantoprazole: a relevant interaction or not? Br J Clin Pharmacol. 2010;70:908-11. 
13. Hilton JF, Tu D, Seymour L, Shepherd FA, Bradbury PA. An evaluation of the possible interaction of gastric acid suppressing medication and the EGFR tyrosine kinase inhibitor erlotinib. Lung Cancer. 2013;82:136-42.

14. Fukudo M, Ikemi Y, Togashi Y, Masago K, Kim YH, Mio T et al. Population pharmacokinetics/pharmacodynamics of erlotinib and pharmacogenomic analysis of plasma and cerebrospinal fluid drug concentrations in Japanese patients with non-small cell lung cancer. Clin Pharmacokinet. 2013;52:593-609.

15. Kletzl H, Giraudon M, Ducray PS, Abt M, Hamilton M, Lum BL. Effect of gastric pH on erlotinib pharmacokinetics in healthy individuals: omeprazole and ranitidine. Anticancer Drugs. $2015 ; 26: 565-72$.

16. Tsai HH, Lin HW, Simon Pickard A, Tsai HY, Mahady GB. Evaluation of documented drug interactions and contraindications associated with herbs and dietary supplements: a systematic literature review. Int J Clin Pract. 2012;66:1056-78.

17. Scheife RT, Hines LE, Boyce RD, Chung SP, Momper JD, Sommer CD et al. Consensus recommendations for systematic evaluation of drug-drug interaction evidence for clinical decision support. Drug Saf. 2015;38:197-206.

18. van Leeuwen RW, Jansman FG, van den Bemt PM, de Man F, Piran F, Vincenten I et al. Drug-drug interactions in patients treated for cancer: a prospective study on clinical interventions. Ann Oncol. 2015;26:992-7.

19. Carcelero E, Anglada H, Tuset M, Creus N. Interactions between oral antineoplastic agents and concomitant medication: a systematic review. Expert Opin Drug Saf. 2013;12:403-20.

20. Wong CM, Ko Y, Chan A. Clinically significant drug-drug interactions between oral anticancer agents and nonanticancer agents: profiling and comparison of two drug compendia. Ann Pharmacother. 2008;42:1737-48. 
Table 1. Targeted cancer therapy included in the review.

\begin{tabular}{|c|c|c|c|}
\hline Drug & $\begin{array}{l}\text { Mechanism of } \\
\text { action }\end{array}$ & $\begin{array}{l}\text { Molecular } \\
\text { target }\end{array}$ & Type of cancer \\
\hline \multicolumn{4}{|c|}{ Signal transduction inhibitors } \\
\hline Afatinib & TKI & EGFR & Non-small cell lung cancer \\
\hline Axitinib & TKI & $\begin{array}{l}\text { VEGFR1-3 } \\
\text { PDGFR } \alpha / \beta, \mathrm{c}- \\
\text { KIT, FLT-3, } \\
\text { CSF-1R, RET }\end{array}$ & Renal cell carcinoma \\
\hline Bosutinib & TKI & BCR-ABL & Chronic myelogenous leukemia \\
\hline Cabozantinib & TKI & $\begin{array}{l}\text { c-MET- } \\
\text { VEGFR1-3, } \\
\text { TIE-2, Kit, } \\
\text { RET, FL-3, } \\
\text { TRKB, AXL }\end{array}$ & Medullary thyroid cancer \\
\hline Cobimetinib & $\begin{array}{l}\text { Serine/Threonine } \\
\text { kinase Inhibitor }\end{array}$ & MEK & $\begin{array}{l}\text { Metastatic melanoma with BRAF V600 } \\
\text { mutation } \\
\text { in combination with vemurafenib }\end{array}$ \\
\hline Crizotinib & TKI & ALK & Non-small cell lung cancer \\
\hline Dabrafenib & $\begin{array}{l}\text { Serine/Threonine } \\
\text { kinase Inhibitor }\end{array}$ & B-Raf & $\begin{array}{l}\text { Metastatic melanoma with BRAF V600 } \\
\text { mutation }\end{array}$ \\
\hline Dasatinib & TKI & $\begin{array}{l}\text { BCR-ABL, } \\
\text { Src family, } \\
\text { ephrin } \\
\text { receptor, c-kit } \\
\text { y PDGFR }\end{array}$ & $\begin{array}{l}\text { Acute lymphoblastic leukemia Phi+ } \\
\text { Chronic myelogenous leukemia Phi+ }\end{array}$ \\
\hline Erlotinib & TKI & EGFR & $\begin{array}{l}\text { Non-small cell lung cancer } \\
\text { Pancreatic cancer }\end{array}$ \\
\hline Everolimus & mTOR Inhibitor & mTOR1 & $\begin{array}{l}\text { Breast cancer } \\
\text { Pancreatic cancer } \\
\text { Renal cell carcinoma } \\
\text { Subependymal giant cell astrocytoma }\end{array}$ \\
\hline Gefitinib & TKI & EGFR & Non-small cell lung cancer \\
\hline Ibrutinib & TKI & $\begin{array}{l}\text { Bruton's } \\
\text { tyrosine } \\
\text { kinase }\end{array}$ & $\begin{array}{l}\text { Chronic lymphocytic leukaemia } \\
\text { Mantle cell lymphoma }\end{array}$ \\
\hline Imatinib & TKI & $\begin{array}{l}\text { BCR-ABL, c- } \\
\text { kit, PDGFR }\end{array}$ & $\begin{array}{l}\text { Acute lymphoblastic leukemia Phi+ } \\
\text { Chronic eosinophilic leukemia or } \\
\text { hypereosinophilic syndrome. } \\
\text { Chronic myelogenous leukemia } \\
\text { Dermatofibrosarcoma protuberans. } \\
\text { Gastrointestinal stromal tumor (GIST) } \\
\text { Myelodysplastic/myeloproliferative } \\
\text { neoplasms. } \\
\text { Systemic mastocytosis. }\end{array}$ \\
\hline Lapatinib & TKI & $\begin{array}{l}\text { HER2 y } \\
\text { EGFR }\end{array}$ & Breast cancer \\
\hline Nilotinib & TKI & $\begin{array}{l}\text { BCR-ABL, c- } \\
\text { kit y PDGFR }\end{array}$ & Chronic myelogenous leukemia \\
\hline Nintedanib & TKI & $\begin{array}{l}\text { VEGFR 1-3, } \\
\text { PDGFR, } \\
\text { FGFR 1-3 }\end{array}$ & Non-small cell lung cancer \\
\hline Olaparib & PARP inhibitor & PARP1/2 & Ovarian cancer \\
\hline
\end{tabular}




\begin{tabular}{|c|c|c|c|}
\hline Pazopanib & TKI & $\begin{array}{l}\text { VEGFR1/3, } \\
\text { PDGFR, kit }\end{array}$ & $\begin{array}{l}\text { Renal cell carcinoma } \\
\text { Soft tissue sarcoma }\end{array}$ \\
\hline Ponatinib & TKI & BCR-ABL & $\begin{array}{l}\text { Acute lymphoblastic leukemia Phi+ } \\
\text { Chronic myelogenous leukemia Phi+ }\end{array}$ \\
\hline Regorafenib & TKI & $\begin{array}{l}\text { VEGFR1-3, } \\
\text { TIE2, c-kit, } \\
\text { RET, BRAF, } \\
\text { EGFR-1, } \\
\text { PDFGR }\end{array}$ & $\begin{array}{l}\text { Colorectal cancer } \\
\text { GIST }\end{array}$ \\
\hline Ruxolitinib & TKI & $\begin{array}{l}\text { Janus } \\
\text { Associated } \\
\text { Kinases } \\
(\text { JAK1,JAK2) } \\
\end{array}$ & $\begin{array}{l}\text { Myelofibrosis } \\
\text { Polycythemia vera }\end{array}$ \\
\hline Sorafenib & TKI & $\begin{array}{l}\text { VEGFR1 y } 2 \\
\text { PDGFR } \beta \text { y } \\
\text { Raf }\end{array}$ & $\begin{array}{l}\text { Hepatocellular carcinoma } \\
\text { Renal cell carcinoma } \\
\text { Thyroid cancer }\end{array}$ \\
\hline Sunitinib & TKI & $\begin{array}{l}\text { VEGFR1-3, } \\
\text { PDGFR,c-kit }\end{array}$ & $\begin{array}{l}\text { GIST } \\
\text { Pancreatic neuroendocrine cancer } \\
\text { Renal cell cancer }\end{array}$ \\
\hline Temsirolimus & mTOR inhibitor & mTOR1 & Renal cell carcinoma \\
\hline Trametinib & $\begin{array}{l}\text { Serine/Threonine } \\
\text { kinase Inhibitor }\end{array}$ & MEK & $\begin{array}{l}\text { Metastatic melanoma with BRAF V600 } \\
\text { mutation } \\
\text { in combination with dabrafenib }\end{array}$ \\
\hline Vandetanib & TKI & $\begin{array}{l}\text { VEGFR2, } \\
\text { EGFR, RET }\end{array}$ & Medullary thyroid cancer \\
\hline Vemurafenib & $\begin{array}{l}\text { Serine/Threonine } \\
\text { kinase Inhibitor }\end{array}$ & B-Raf & $\begin{array}{l}\text { Metastatic melanoma with BRAF V600 } \\
\text { mutation }\end{array}$ \\
\hline Vismodegib & TKI & $\begin{array}{l}\text { 'Hedgegoh' } \\
\text { signalling } \\
\text { pathway, } \\
\text { PTCH1, GLI1 }\end{array}$ & Basal cell carcinoma \\
\hline \multicolumn{4}{|c|}{ Monoclonal Antibodies (MoAb) } \\
\hline Alemtuzumab & MoAb & CD52 & B-cell chronic lymphocytic leukemia \\
\hline Bevacizumab & $\mathrm{MoAb}$ & VEGF & $\begin{array}{l}\text { Cervical } \\
\text { Colorectal cancer } \\
\text { Glioblastoma } \\
\text { Non-small cell lung cancer } \\
\text { Ovarian epithelial, fallopian tube, or primary } \\
\text { peritoneal cancer } \\
\text { Renal cell cancer }\end{array}$ \\
\hline Brentuximab & $\mathrm{MoAb}$ & CD30 & $\begin{array}{l}\text { Anaplastic large cell lymphoma } \\
\text { Hodgkin lymphoma }\end{array}$ \\
\hline Cetuximab & $\mathrm{MoAb}$ & EGFR & $\begin{array}{l}\text { Colorectal cancer } \\
\text { Squamous cell carcinoma of the head and } \\
\text { neck }\end{array}$ \\
\hline Ofatumumab & MoAb & CD20 & Chronic lymphocytic leukemia \\
\hline Panitumumab & $\mathrm{MoAb}$ & EGFR & Colorectal cancer \\
\hline Pertuzumab & $\mathrm{MoAb}$ & HER2 & Breast cancer \\
\hline Ramucirumab & $\mathrm{MoAb}$ & VEGFR2 & $\begin{array}{l}\text { Adenocarcinoma of the stomach or } \\
\text { gastroesophageal junction } \\
\text { Colorectal cancer } \\
\text { Non-small cell lung cancer }\end{array}$ \\
\hline Rituximab & MoAb & CD20 & B-cell non-Hodgkin lymphoma \\
\hline
\end{tabular}




\begin{tabular}{|l|l|l|l|}
\hline & & & Chronic lymphocytic leukemia \\
\hline Trastuzumab & MoAb & HER2 & $\begin{array}{l}\text { Breast cancer } \\
\text { Adenocarcinoma of the stomach or } \\
\text { gastroesophageal junction }\end{array}$ \\
\hline \multicolumn{3}{|c|}{ Others } \\
\hline Aflibercept & $\begin{array}{l}\text { Recombinant } \\
\text { fusion protein }\end{array}$ & $\begin{array}{l}\text { VEGF-A-B, } \\
\text { PlGF }\end{array}$ & Colorectal cancer \\
\hline $\begin{array}{l}\text { Trastuzumab } \\
\text { T-DM1 }\end{array}$ & MoAb conjugate & HER2 & Breast cancer \\
\hline
\end{tabular}

TKI $=$ Tirosine kinase inhibitor

ALK = anaplastic lymphoma kinase

EGFR $=$ Epidermal Growth Factor Receptor

PARP $=$ Poly (ADP-ribose) polymerase

PTCH1= Patched Homolog 1

GLI1= Glioma-associated protein 1 
Table 2. Drug-drug interactions

\begin{tabular}{|c|c|c|c|c|c|c|c|c|}
\hline Drug & Substrate & Inhibits & Induces & $\begin{array}{l}\text { Renal } \\
\text { elimination } \\
\text { Interactions } \\
\text { (\% renal } \\
\text { elimination) }\end{array}$ & $\begin{array}{l}\text { DDI w/ Drugs } \\
\text { affecting } \\
\text { gastric acidity }\end{array}$ & $\begin{array}{l}\text { Coumarin } \\
\text { Effects }\end{array}$ & $\begin{array}{l}\text { Prolong } \\
\text { s QTe }\end{array}$ & Specific recommendations \\
\hline -Afatinib & BCRP, P-gp & BCRP, P-gp & - & No $(4 \%)$ & Not studied & No & No & $\begin{array}{l}\text {-P-gp inducers/inhibitors: increase } \\
\text { afatinib by } 10 \mathrm{mg} / \text { reduce by } 10 \mathrm{mg}\end{array}$ \\
\hline -Axitinib & $\begin{array}{l}\text { CYP3A4*, } \\
\text { 3A5*, 1A2- } \\
\text {,C19-, } \\
\text { UGT1A1- }\end{array}$ & $\begin{array}{l}\text { CYP1A2-, } \\
\text { 2C8- }\end{array}$ & - & No $(23 \%)$ & No & Possible & No & $\begin{array}{l}\text {-Strong CYP3A4 inh: decrease dose } \\
\text { axitinib by } 50 \% \\
\text {-Avoid strong CYP3A4 inducers } \\
\text {-Monitor INR }\end{array}$ \\
\hline - Bosutinib & $\begin{array}{l}\text { CYP3A4*, P- } \\
\text { gp }\end{array}$ & P-gp & - & No $(3 \%)$ & Yes & No & Yes & $\begin{array}{l}\text {-Avoid strong ind/inh CYP3A4 } \\
\text {-Avoid PPIs; if AntiH2 or antiacids, } \\
\text { separate } 2 \mathrm{~h}\end{array}$ \\
\hline -Cabozantinib & $\begin{array}{l}\text { CYP3A4*, } \\
\text { CYP2C9- }\end{array}$ & P-gp & - & No $(27 \%)$ & Not studied & Not studied & Possible & $\begin{array}{l}\text {-Strong CYP3A4 ind/inh: increase } \\
\text { /decrease cabozantinib dose by } 40 \mathrm{mg} \\
\text { (max dose } 180 \mathrm{mg})\end{array}$ \\
\hline Cobimetinib & $\begin{array}{l}\text { CYP3A4*, } \\
\text { P-gp }\end{array}$ & $\begin{array}{l}\text { CYP3A-, } \\
\text { 2D6- }\end{array}$ & - & No $(18 \%)$ & Not studied & Not studied & $\begin{array}{l}\text { Not } \\
\text { known }\end{array}$ & $\begin{array}{l}\text {-Avoid strong ind CYP3A4 } \\
\text {-Strong CYP3A4 inh: reduce } \\
\text { cobimetinib to } 20 \mathrm{mg} / \text { daily. }\end{array}$ \\
\hline Crizotinib & $\begin{array}{l}\text { CYP3A4*, P- } \\
\text { gp,OATP1B1- } \\
\text {,OATP1B3- }\end{array}$ & $\begin{array}{l}3 \mathrm{~A} 4++, \mathrm{P}- \\
\text { gp, } \\
\mathrm{AB} 6+++\end{array}$ & - & No (2\%) & Possible & Not studied & Yes & $\begin{array}{l}\text { - Avoid strong ind/inh CYP3A4 } \\
\text {-PPIs, AntiH2 and antiacids may } \\
\text { decrease bioavailability of crizotinib }\end{array}$ \\
\hline -Dabrafenib & $\begin{array}{l}\text { CYP3A4*, } \\
\text { 2C8*, P-gp, } \\
\text { BCRP }\end{array}$ & $\begin{array}{l}\text { BCRP++, } \\
\text { OATP1B1- } \\
\text {,OATP1B3- }\end{array}$ & $\begin{array}{l}\text { CYP3A4++, } \\
\text { 2B6, 2C8, } \\
\text { 2C19, UDP }\end{array}$ & No $(23 \%)$ & Possible & Yes & $\begin{array}{l}\text { Not } \\
\text { studied }\end{array}$ & -Decrease bioavailability of warfarin \\
\hline - Dasatinib & CYP3A4* & $3 \mathrm{~A} 4+$ & - & No $(4 \%)$ & Yes & Possible & Yes & $\begin{array}{l}\text {-Avoid strong inducers CYP3A4 } \\
\text {-If strong CYP3A4 inhibitors: decrease } \\
\text { dose of dasatinib to } 20 \mathrm{mg} \text { or } 40 \mathrm{mg} \text { (if } \\
\text { 100mg or } 140 \mathrm{mg} \text { respectively) } \\
\text {-Avoid PPI or antiH2. }\end{array}$ \\
\hline
\end{tabular}




\begin{tabular}{|c|c|c|c|c|c|c|c|c|}
\hline & & & & & & & & $\begin{array}{l}\text { Antiacids (separated 2h) } \\
\text {-Monitor INR }\end{array}$ \\
\hline - Erlotinib & $\begin{array}{l}\text { CYP3A4*, } \\
\text { 1A2- }\end{array}$ & $\begin{array}{l}\text { UGT1A1++ } \\
+\end{array}$ & - & No $(8 \%)$ & Yes & Yes & $\begin{array}{l}\text { Not } \\
\text { studied }\end{array}$ & $\begin{array}{l}\text {-Strong CYP3A4 ind/inh: } \\
\text { increase/decrease dose of erlotinib by } \\
\text { fractions of } 50 \mathrm{mg} \text { (max dose } 450 \mathrm{mg} \text { ). } \\
\text {-Avoid PPI, separate antiH } 210 \mathrm{~h} \text { after } \\
\text { and } 2 \mathrm{~h} \text { before } \\
\text {-Monitor INR }\end{array}$ \\
\hline -Everolimus & $\begin{array}{l}\text { CYP3A4*, P- } \\
\text { gp- }\end{array}$ & P-gp++ & - & No $(5 \%)$ & Not studied & Not studied & No & $\begin{array}{l}\text {-Strong inh CYP3A4: decrease dose of } \\
\text { everolimus to } 2.5 \mathrm{mg} \\
\text {-Strong ind CYP3A4 increase } \\
\text { everolimus in } 5 \mathrm{mg} \text { increments (max } \\
\text { dose 20mg) } \\
\text {-Monitor with cyclosporine and other } \\
\text { nephrotoxic agents }\end{array}$ \\
\hline - Gefitinib & $\begin{array}{l}\text { CYP3A4*, } \\
\text { 2D6* }\end{array}$ & $\begin{array}{l}\text { BCRP, } \\
2 \mathrm{C} 19+ \\
2 \mathrm{D} 6+\end{array}$ & - & No $(<4 \%)$ & Yes & Yes & $\begin{array}{l}\text { Not } \\
\text { studied }\end{array}$ & $\begin{array}{l}\text {-Strong ind CYP3A4 consider gefitinib } \\
\text { 500mg/day } \\
\text {-PPI separate } 12 \mathrm{~h} \text {; antiH2 and } \\
\text { antiacids separate } 6 \mathrm{~h} . \\
\text {-Monitor INR }\end{array}$ \\
\hline - Ibrutinib & $\begin{array}{l}\text { CYP3A4* } \\
\text { 2D6- }\end{array}$ & P-gp+ & - & No $(<10 \%)$ & Not studied & Yes & $\begin{array}{l}\text { Not } \\
\text { studied }\end{array}$ & $\begin{array}{l}\text {-Avoid strong ind/inh CYP3A4 } \\
\text {-Monitor INR }\end{array}$ \\
\hline - Imatinib & $\begin{array}{l}\text { CYP,3A4*, } \\
3 \mathrm{~A} 5^{*}, 1 \mathrm{~A} 2- \\
\text { 2C9-, 2D6-, } \\
\text { 2C19-, P-gp- }\end{array}$ & $\begin{array}{l}\text { CYP } \\
3 \mathrm{~A} 4++, \\
3 \mathrm{~A} 5++, \\
2 \mathrm{C} 9+, \\
2 \mathrm{D} 6++ \\
\text { BCRP }++ \\
\text { P-gp }\end{array}$ & - & No (13\%) & Not studied & Yes & $\begin{array}{l}\text { Not } \\
\text { studied }\end{array}$ & $\begin{array}{l}\text {-Strong ind CYP3A4, increase dose by } \\
50 \% \text { imatinib } \\
\text {-Increased INR }\end{array}$ \\
\hline -Lapatinib & $\begin{array}{l}\text { CYP 3A4*, P- } \\
\text { gp }\end{array}$ & $\begin{array}{l}\text { P-gp, 3A4+, } \\
\text { 2C8++, } \\
\text { BCRP }\end{array}$ & - & No $(<2 \%)$ & Not studied & No & Yes & $\begin{array}{l}\text {-Strong ind CYP3A4 increase lapatinib } \\
\text { gradually up to } 4500 \mathrm{mg} \\
\text {-Strong inh CYP3A4 decrease }\end{array}$ \\
\hline
\end{tabular}




\begin{tabular}{|c|c|c|c|c|c|c|c|c|}
\hline & & & & & & & & lapatinib to $500 \mathrm{mg}$ \\
\hline - Nilotinib & $\begin{array}{l}\text { CYP3A4*, P- } \\
\text { gp }\end{array}$ & $\begin{array}{l}\text { CYP3A4++ } \\
, 2 \mathrm{C} 9+, \\
\text { 2D6++, } \\
\text { 2C8++, P- } \\
\text { gp, } \\
\text { UGT1A1 }\end{array}$ & $\begin{array}{l}\text { CYP2B6++, } \\
2 \mathrm{C} 8++, \\
2 \mathrm{C} 9++\end{array}$ & No $(<1 \%)$ & Yes & No & Yes & $\begin{array}{l}\text {-Avoid PPI, } \\
\text { Use separated antiH2 or antiacids } 10 \mathrm{~h} \\
\text { after and } 2 \mathrm{~h} \text { before }\end{array}$ \\
\hline - Nintedanib & $\begin{array}{l}\text { CYP3A4, P- } \\
\text { gp }\end{array}$ & - & - & No $(<1 \%)$ & Not studied & Yes & No & -Monitor INR \\
\hline -Olaparib & $\begin{array}{l}\text { CYP 3A4*, P- } \\
\text { gp }\end{array}$ & $\begin{array}{l}\text { BCRP, } \\
\text { OATP1B1, } \\
\text { OCT1, } \\
\text { OCT2, P-gp }\end{array}$ & - & $\begin{array}{l}\text { No }(44 \% \\
\text { inactive } \\
\text { metabolites) }\end{array}$ & Not studied & No & $\begin{array}{l}\text { Not } \\
\text { studied }\end{array}$ & $\begin{array}{l}\text {-Avoid strong CYP3A4 inducers } \\
\text {-Strong CYP3A4 inhibitors: decrease } \\
\text { olaparib to } 150 \mathrm{mg} \text { twice daily }\end{array}$ \\
\hline -Pazopanib & $\begin{array}{l}\text { CYP3A4*, } \\
\text { 1A2-, 2C8-, } \\
\text { P-gp, BCRP }\end{array}$ & $\begin{array}{l}\text { CYP2C8+, } \\
\text { 2D6+, } \\
\text { 3A4+, } \\
\text { OATP1b1, } \\
\text { UGT1A1 }\end{array}$ & - & No $(<4 \%)$ & Yes & No & Yes & $\begin{array}{l}\text {-Avoid strong CYP3A4 inducers } \\
\text {-Strong inh CYP3A4 decrease } \\
\text { pazopanib dose to } 400 \mathrm{mg} \\
\text {-Avoid PPI, antiacids and antiH2 }\end{array}$ \\
\hline -Ponatinib & $\begin{array}{l}\text { CYP3A4-, } \\
\text { 2C8-, 2D6-, } \\
\text { P-gp-, BCRP- }\end{array}$ & $\begin{array}{l}\text { P-gp, } \\
\text { BCRP, } \\
\text { BSEP }\end{array}$ & - & No (5\% aprox) & Possible & Not studied & No & $\begin{array}{l}\text {-Strong inh CYP3A4 : decrease } \\
\text { ponatinib dose to } 30 \mathrm{mg} \text { daily } \\
\text {-Avoid antiacids if possible }\end{array}$ \\
\hline -Regorafenib & $\begin{array}{l}\text { CYP3A4*, } \\
\text { UGT1A9 }\end{array}$ & $\begin{array}{l}\text { CYP2C8, } \\
\text { 2C9, 2B6, } \\
\text { 3A4, 2C19, } \\
\text { UGT1A9, } \\
\text { UGT1A1, } \\
\text { BCRP, P-gp }\end{array}$ & - & No (19\%) & No & Yes & No & $\begin{array}{l}\text {-Avoid strong ind/inh CYP3A4 } \\
\text {-Increase INR }\end{array}$ \\
\hline -Ruxolitinib & CYP3A4* & - & - & $\begin{array}{l}\text { No }(74 \% \\
\text { inactive } \\
\text { metabolites) }\end{array}$ & No & Not studied & Yes & $\begin{array}{l}\text {-Strong CYP3A4 inhibitors: decrease } \\
\text { ruxolitinib dose by } 50 \% \text {; if platelets } \\
<100,000 / \mathrm{mm} 3 \text {, avoid } \\
\text { coadministration }\end{array}$ \\
\hline -Sorafenib & CYP3A4-, & CYP2B6++, & - & No $(19 \%)$ & No & Yes & Yes & -Monitor INR \\
\hline
\end{tabular}




\begin{tabular}{|c|c|c|c|c|c|c|c|c|}
\hline & UGT1A9 & $\begin{array}{l}\text { 2C9++, } \\
\text { 2C8+, } \\
\text { UGT1A1, } \\
\text { UGT1A9, } \\
\text { BCRP, } \\
\text { BSEP }\end{array}$ & & & & & & \\
\hline -Sunitinib & CYP3A4* & BCRP, P-gp & - & No $(16 \%)$ & Not studied & Not studied & Yes & $\begin{array}{l}\text {-Strong inh CYP3A4 decrease } \\
\text { sunitinib dose to } 37,5 \mathrm{mg} \text { (GIST/RCC) } \\
\text { or } 25 \mathrm{mg} \text { (PNET) } \\
\text {-Strong ind CYP3A4 increase sunitinib } \\
\text { to } 87,5 \mathrm{mg} \text { (GIST/RCC) or } 62,5 \mathrm{mg} \\
\text { (PNET) }\end{array}$ \\
\hline -Temsirolimus & $\begin{array}{l}\text { CYP3A4*, P- } \\
\text { gp }\end{array}$ & CYP2D6+ & - & No $(<5 \%)$ & N/A & Yes & No & $\begin{array}{l}\text {-Avoid strong inh CYP3A4 } \\
\text {-Increase risk of bleeding in the brain }\end{array}$ \\
\hline - Trametinib & - & CYP2C8+ & CYP3A4+ & No $(<20 \%)$ & Not studied & Not studied & $\begin{array}{l}\text { Not } \\
\text { studied }\end{array}$ & -Not substrate of CYP, P-gp or BCRP \\
\hline -Vandetanib & CYP3A4* & P-gp, BCRP & - & $\begin{array}{l}\text { No }(25 \% \\
\text { aprox })\end{array}$ & No & Not studied & Yes & $\begin{array}{l}\text {-QTc: deaths reported, monitor closely } \\
\text { electrolyte imbalance before initiation } \\
\text { and ECG at baseline }\end{array}$ \\
\hline -Vemurafenib & $\begin{array}{l}\text { CYP3A4*, P- } \\
\text { gp, BCRP }\end{array}$ & $\begin{array}{l}\text { CYP1A2++ } \\
\text {, 2D6+, P- } \\
\text { gp, BCRP }\end{array}$ & CYP3A4+ & No $(<1 \%)$ & No & Yes & Yes & -Monitor INR \\
\hline -Vismodegib & $\begin{array}{l}\text { CYP3A4-, } \\
\text { 2C9-, P-gp }\end{array}$ & $\begin{array}{l}\text { CYP2C } 8+, 2 \\
\text { C9+,2C19+, } \\
\text { BCRP }\end{array}$ & - & No $(4 \%)$ & Possible & Possible & No & $\begin{array}{l}\text {-Altered } \mathrm{pH} \text { may reduce bioavailability } \\
\text { but not studied } \\
\text {-Monitor INR }\end{array}$ \\
\hline Alemtuzumab & - & - & - & - & N/A & Not studied & $\begin{array}{l}\text { Not } \\
\text { studied }\end{array}$ & - \\
\hline Bevacizumab & - & - & - & - & N/A & Not studied & $\begin{array}{l}\text { Not } \\
\text { studied }\end{array}$ & $\begin{array}{l}\text {-Increase cardiotoxicity with } \\
\text { anthracyclines } \\
\text {-Increase toxicity of irinotecan (33\%) } \\
\text {-Avoid sunitinib (cases of MAHA) }\end{array}$ \\
\hline Cetuximab & - & - & - & - & N/A & Not studied & Not & - \\
\hline
\end{tabular}




\begin{tabular}{|c|c|c|c|c|c|c|c|c|}
\hline & & & & & & & studied & \\
\hline Ofatumumab & - & - & - & - & N/A & Not studied & $\begin{array}{l}\text { Not } \\
\text { studied }\end{array}$ & - \\
\hline Panitumumab & - & - & - & - & N/A & Not studied & $\begin{array}{l}\text { Not } \\
\text { studied }\end{array}$ & - \\
\hline Pertuzumab & - & - & - & - & N/A & Not studied & $\begin{array}{l}\text { Not } \\
\text { studied }\end{array}$ & - \\
\hline Ramucirumab & - & - & - & - & N/A & Not studied & $\begin{array}{l}\begin{array}{l}\text { Not } \\
\text { studied }\end{array} \\
\end{array}$ & - \\
\hline Rituximab & - & - & - & - & N/A & Not studied & $\begin{array}{l}\text { Not } \\
\text { studied }\end{array}$ & - \\
\hline Trastuzumab & - & - & - & - & N/A & Not studied & $\begin{array}{l}\text { Not } \\
\text { studied }\end{array}$ & - \\
\hline Aflibercept & - & - & - & - & N/A & Not studied & $\begin{array}{l}\text { Not } \\
\text { studied }\end{array}$ & - \\
\hline Brentuximab & $\begin{array}{l}\text { CYP3A4*, } \\
\text { 3A5, P-gp, } \\
\text { 2D6- }\end{array}$ & CYP3A4- & - & - & N/A & Not studied & $\begin{array}{l}\text { Not } \\
\text { studied }\end{array}$ & $\begin{array}{l}\text {-Monitor toxicity with strong inh/ind } \\
\text { CYP3A4 }\end{array}$ \\
\hline $\begin{array}{l}\text { Trastuzumab } \\
\text { emtasine } \\
\text { T-DM1 }\end{array}$ & $\begin{array}{l}\text { CYP3A4* } \\
\text { (DM1), 3A5- }\end{array}$ & - & - & - & N/A & Not studied & $\begin{array}{l}\text { Not } \\
\text { studied }\end{array}$ & $\begin{array}{l}\text {-Delay treatments with ind/inh } \\
\text { CYP3A4 }\end{array}$ \\
\hline
\end{tabular}

NOTE: *Indicates major substrate; -, minor substrate; +, weak inducer/inhibitor; ++, moderate inducer/inhibitor; and +++ strong inducer/inhibitor

Abbreviations: BCRP, breast cancer resistance protein; BSEP, bile salt export pump; DDI, drug-drug interaction; GIST, GI stromal tumor; MAHA, microangiopathic hemolytic anemia; OATP, organic anion-transporting polypeptide; P-gp, P-glycoprotein; PNET, primitive neuroectodermal tumor; RCC, renal cell carcinoma; UGT, UDP uridine diphosphate glucuronosyltransferase 